\title{
Pro-Vaccination Attitude and Associated Factors Towards COVID-19 Vaccine among Healthcare Workers and Nonhealthcare Workers: "A Call for Action"-A Systematic Review
}

Addisu Wake ( $\square$ addansa12@gmail.com )

Arsi University

\section{Research Article}

Keywords: knowledge, attitude, COVID-19, vaccine, associated factors, systematic review

Posted Date: November 23rd, 2021

DOI: https://doi.org/10.21203/rs.3.rs-1030439/v1

License: (c) (1) This work is licensed under a Creative Commons Attribution 4.0 International License. Read Full License 


\section{Abstract}

Introduction: Coronavirus disease 2019 (COVID-19) pandemic hasn't been managed and controlled effectively, globally. The aim of this systematic review was to determine Pro-vaccination attitude and associated factors towards COVID-19 vaccine among healthcare workers (HCWs) and nonhealthcare workers (non-HCWs).

Methods: Different databases such as PsycINFO, HINARI, Cochrane Library, PubMed, EMBASE, African Journals OnLine, Web of Science, Scopus, and Google Scholar for the related articles.

Result: The levels of positive attitude towards COVID-19 vaccine among HCWs was ranged from $21 \%$ to $95 \%$. Factors significantly associated with the attitude towards COVID-19 vaccine among HCWs were such as age, gender, race, work experience, home location, having no fear of injections, being a non-smoker, profession, presence of chronic illnesses, allergies, confidence in pharmaceutical companies, history of taking influenza vaccine, vaccine recommendation, perceived risk of new vaccines, perceived utility of vaccine, receiving a seasonal flu vaccination in the last 5 years, working in a private hospital, a high perceived pandemic risk index, low vaccine harm index, high pro-socialness index, being in close contact with a high-risk group, knowledge about the virus, confidence in and expectations about personal protective equipment and behaviors. The levels of positive attitude towards COVID-19 vaccine among non-HCWs was ranged from $21.4 \%$ to $91.99 \%$. Factors associated with the attitude towards COVID-19 vaccine among non-HCWs were such as age, gender, educational level, occupation, marital status, residency, income, ethnicity, risk for severe course of COVID-19, direct contact with COVID-19 at work, being a health profession, being vaccinated against seasonal flu, perceived benefits, cues to actions, having previous history of vaccination, fear of passing on the disease to relatives, and the year of medical study, studying health-related courses, COVID-19 concern, adherence level to social distancing guidelines, history of chronic disease, being pregnancy, perceived vaccine safety, having more information about vaccine effectiveness, mandatory vaccination, being recommended to be vaccinated, lack of the confidence in the healthcare system to control epidemic, and believe in COVID-19 vaccines protection from COVID-19 infection.

Conclusion: The level of positive attitude towards COVID-19 vaccine among both HCWs and non-HCWs were unfavorable and comparable. Globally, there is a need for a call for action to cease the time and crisis of this pandemic.

\section{Introduction}

COVID-19 pandemic has spread swiftly over all countries [1]. COVID-19 remains to destroy the world [2]. This pandemic has put a challenge across all the countries [3], since it was described as a pandemic [4]. It is a worldwide public emergency [5]. It affected all persons globally[6]. COVID-19 put a significant burden comprising morbidity and mortality [7, 8]. It has also led to substantial economic disasters besides mortality and morbidity [9]. This pandemic has also led to mental health worsening of the families who had children [10], the entire population [11], and also massive effect mental health of the youth [12]. It has also incredibly affected the development of children [13], and markedly interrupted vaccination of the children [14]. Furthermore, this pandemic has also momentous stress on patients, healthcare systems, and HCWs [15]. It has also affected the treatment and prevention of chronic cases such as tuberculosis and human immunodeficiency virus [16]. COVID-19 put an extensive problem on the African continent [17], a poor and susceptible population [9].

Thus, these impacts need urgent measures across all countries [18]. Because of a lack of a vaccine, diverse prevention approaches were executed [19]. For instance; limits of large gatherings, travel bans, school closures, and country lockdown [9]. A vaccine offers the greatest hope for a permanent solution to control it [2]. Since COVID-19 is continuing its impact all over the countries, the government should be equipped to distribute a COVID-19 vaccine accordingly [20]. The intention for vaccine against COVID-19 is determined by the information concerning to the people variety, vaccine efficacy, and vaccine development [21]. Since there are controversies regarding a safety and efficacy of this vaccine, this may declines the vaccination rates [22]. Vaccine hesitancy may lead to the decrement in the need of the population for a COVID-19 vaccine [23]. Besides, the people unwillingness for this vaccine will determine the COVID-19 response and public health 
benefits' of an effective vaccine [24]. The effectiveness of COVID-19 vaccine will be tested by vaccine hesitancy [25]. Only a small proportion of the parents had agreed to vaccinate for COVID-19 their children [26]. About one-third of the caregivers were reluctant to vaccinate their children [27]. The parents are not agreed to join their child, even in a clinical trial for this vaccine [28]. This would delay the time of the pandemic, because all these factors affect the attainment of herd immunity for this pandemic [29].

Knowing the intention for this vaccine will assist for the application of effective methods to improve this vaccination [30]. Lessening vaccination hesitancy concerning COVID-19 to control it may be as notable as determining a safe and effective vaccine [31]. It is an ethical and humanistic responsibility to approve that this vaccine is safe for the public [32]. It is vital to permit HCWs and the community to have access to reliable and satisfactory evidence about this vaccine to increase its acceptance rate [33]. The attitude of the HCWs regarding COVID-19 vaccine affects themselves to use the vaccine and their willingness to recommend for the patients. Therefore that, future education should prioritize for HCWs to the population to accept it [34]. HCWs who refuse to have vaccination are often accused of exposing their patients to a lethal infection [35]. It is acceptable that vaccines are a very significant population health measures to defend individuals from this pandemic. Besides, HCWs accounted for a considerable figure of infected individuals [36].

The development of SARS-CoV-2 virus vaccine puts in itself a new test for the governments and health authorities [37]. HCWs are at high risk of COVID-19 [38, 39]. The pandemic among these populations is a main worry for health authorities worldwide. While COVID-19 infection in HCWs would have an instant consequence on their occupation and the whole healthcare system [38]. Protecting the HCWs from COVID-19 would be critical to preserve healthcare systems [36]. A vaccine must be acknowledged and used by the population to be effective [2]. Developing a trust communities and intention to take COVID-19 vaccine is as significant as producing a safe and effective vaccine to control this pandemic [40]. The study revealed that the decreased in COVID-19 cases among HCWs started after anti-COVID-19 vaccination, which reveals that COVID-19 vaccines are effective in preventing infection [41].

\section{Methods}

\section{Research Questions}

1. What is the level of Attitude towards COVID-19 vaccine among HCWs and non-HCWs worldwide?

2. What are the factors associated with the level of Attitude towards COVID-19 vaccine among HCWs and non-HCWs?

\section{Study Setting and Search Strategies}

Studies done across worldwide were included in to this systematic review. Different databases such as PsycINFO, HINARI, Cochrane Library, PubMed, EMBASE, African Journals OnLine, Web of Science, Scopus, and Google Scholar were used to search the related articles. The search terms used were; "Attitude”, "perception”, "COVID-19", "SARS-CoV-2", "vaccine”, "associated factors", "determinant factors”, "factors”, “healthcare workers”, “Nurses”, “Midwifes”, “Physician”, "health professional", and "healthcare providers". To integrate these search terms; "AND" and "OR" boolean operators were used.

\section{Eligibility Criteria}

\section{Inclusion criteria}

Studies were included in to the systematic review if they fulfil: cross-sectional studies which reported outcome variables, articles done among adults, and articles published in English language, and articles published up to July 16, 2021 across all countries. 


\section{Exclusion criteria}

Articles which didn't assess the outcome variables, articles which were not fully accessible, and articles with poor quality were excluded from this systematic review.

\section{Outcome Interest}

In this systematic review, the primary outcome was the prevalence of Pro-vaccination attitude towards COVID-19 vaccine among HCWs and non-HCWs. Pro-vaccination attitude was measured by using a "Yes" or "No" question. "Do you intend to have a COVID-19 vaccine in the future?" was the question asked to the participants. The secondary outcome was factors associated with Pro-Vaccination Attitude towards COVID-19 vaccine among HCWs and Non-HCWs which was reported within the included studies.

\section{Data Extraction and Quality Assessment}

The retrieved articles from all databases were exported to Thomson Reuters EndNote version 8. The title and abstract of all possible articles to be included in this systematic review were checked. The standardized data extraction format prepared in a Microsoft Excel worksheet was used to extract the data from the selected articles according to the pre-setted inclusion criteria. The names of the authors, publication year, study period, study country, participants, sample size, study design, prevalence, and factors were used for the extraction of data from each article.

This systematic review has only included cross-sectional studies. The Newcastle-Ottawa Scale (NOS) quality assessment criteria for cross-sectional studies were used to assess the included articles [42, 43], and the modified NOS for cross-sectional studies was used to include the articles. Whereas, all articles with $\geq 5$ out of 10 were considered as a high quality score [44], and included in to this systematic review.

\section{Data Synthesis and Reporting}

This systematic review was conducted on Pro-Vaccination Knowledge, Attitude, and Associated Factors Towards COVID-19 Vaccine among HCWs and Non-HCWs. During this, the Preferred Reporting Items for Systematic reviews and Meta-Analyses (PRISMA) flowchart diagram [45, 46], and PRISMA checklist [46] were used for the study screening, selection, and inclusion in to this systematic review.

\section{Ethics Approval and Consent to Participate}

Not applicable. Since this is a systematic review, there was no data collected from the people.

\section{Results}

\section{Search Results}

All related studies done across the worldwide were identified by using diverse databases. Those databases used to search the related studies were PsycINFO, HINARI, Cochrane Library, PubMed, EMBASE, African Journals OnLine, Web of Science, Scopus, and Google Scholar. From the search made through all these databases, 9,325 studies were found. Due to the duplication found, 4,512 studies were excluded. From the remaining 4,813 studies, 3,835 and 876 studies were omitted because of the titles and abstracts, respectively after carefully checked for their relativeness. A total of 102 studies were screened for eligibility as the pre-setted eligibility criteria. From these, 29 studies were excluded due to lack of the full text, 17 
studies were excluded due to the outcome of interest was not well defined, and 8 studies were excluded due to poor quality. Afterwards, 48 studies were met the predefined eligibility criteria and included in to this systematic review (Figure 1).

\section{Study Characteristics}

This systematic review focused on the studies conducted on Attitude regarding COVID-19 vaccine and its associated factors among the two major population categories, HCWs and non-HCWs. In this systematic review, a total of 48 studies were included, comprising the studies done on both HCWs and non-HCWs participants. There have been substantial differences concerning to the level of attitude towards COVID-19 vaccine among both populations (Table 1).

\section{Attitude Towards COVID-19 Vaccine Among HCWs}

From the total of 48 studies included in to this systematic review, only 19 studies were conducted among HCWs. The smallest and largest sample sizes were reported from Germany (200) [47], and United States (US) $(5,287)$ [48], respectively. The smallest prevalence of a positive attitude towards COVID-19 vaccine among HCWs were reported as $21 \%$ from Egypt [49], while the largest prevalence was 95\%, which was reported from Asia-Pacific [50]. Thus, the prevalence of a positive attitude towards COVID-19 vaccine among HCWs was ranged from $21 \%$ [49] to 95\% [50].

Factors significantly associated with the attitude towards COVID-19 vaccine among HCWs were age, gender, race, work experience, home location, having no fear of injections, being a non-smoker, profession, presence of chronic illnesses, allergies, confidence in pharmaceutical companies, confidence in the management of the epidemic, history of taking influenza vaccine, vaccine recommendation, perceived risk of new vaccines, perceived utility of vaccine, receiving a seasonal flu vaccination in the last 5 years, working in a private hospital, a high perceived pandemic risk index, low vaccine harm index, high pro-socialness index, using Facebook as main information source about antiSARS-CoV-2 vaccination, being in close contact with a high-risk group, having undertaken seasonal flu vaccine during the 2019-2020 season, role within the hospital, knowledge about the virus, confidence in and expectations about personal protective equipment and behaviors (Table 1).

\section{Attitude Towards COVID-19 Vaccine Among Non-HCWs}

Concerning to the non-HCWs, a total of 29 studies were conducted among non-HCWs from 48 studies included in to this systematic review. The smallest and largest sample sizes were reported 90 from United states of America [51], and 32,361 from United kingdom [52], respectively. The smallest prevalence of a positive attitude towards COVID-19 vaccine among nonHCWs were reported as $21.4 \%$ from Lebanon [53], while the largest prevalence was $91.99 \%$, which was reported from Poland [54]. Thus, the prevalence of a positive attitude towards COVID-19 vaccine among non-HCWs was ranged from $21.4 \%$ [53] to $91.99 \%$ [54].

Factors associated with the attitude towards COVID-19 vaccine among non-HCWs were age, gender, educational level, occupation, marital status, residency, income, ethnicity, risk for severe course of COVID-19, direct contact with COVID-19 at work, being a health profession, being vaccinated against seasonal flu, perceived benefits, cues to actions, having previous history of vaccination, fear of passing on the disease to relatives, and the year of medical study, studying health-related courses, COVID-19 concern, adherence level to social distancing guidelines, history of chronic disease, being pregnancy, perceived vaccine safety, having a close acquaintance who did not experience a vaccine-related adverse reaction, having more information about vaccine effectiveness, mandatory vaccination, being recommended to be vaccinated, lack of the confidence in the healthcare system to control epidemic, heard about COVID-19 vaccines, believe in COVID-19 vaccines protection from COVID-19 infection, those who encouraged their family members and friends to get vaccinated (Table 1).

\section{Discussion}


Despite the fact that more than a year has passed since the WHO stated a COVID-19 pandemic, there is no effective treatment yet. The only strategy to halt the virus from spreading is the vaccination of the population as per the recent evidence. However, more populations should to be vaccinated to achieve herd immunity. This is a substantial contest for healthcare systems. Having an effective vaccine is not equivalent to using it, public acceptance is crucial [94]. Besides, despite the consideration of vaccination good achievements of the $20^{\text {th }}$ century, there are remaining public health issues including insufficient, delayed, and unstable vaccination uptake [95]. Generally, the willingness to take the vaccine against COVID-19 will be the next main phase in fighting this pandemic. However, attaining significant uptake will be a contest [96]. Hence, this systematic review was intended to determine the Pro-vaccination attitude and associated factors towards COVID-19 vaccine among HCWs and Non-HCWs globally.

This systematic review has included cross-sectional studies done on the attitude towards COVID-19 vaccine and its associated factors among HCWs and non-HCWs. Recognizing the level of attitude towards COVID-19 vaccine and its associated factors among concerning these two major populations would have a substantial role in managing and controlling this pandemic. This is due to that this study provides critical evidences at the time of this global crisis, which is because of the adverse effects of the COVID-19 pandemic. This is supported by the study which explains that knowing the public needs and factors determining their attitudes towards vaccines would assist to plan for multilevel interventions depending on the evidence to improve vaccine uptake, globally [97]. Generally, to predict and be ready for the future epidemic and pandemic reply, it would be crucial to understand how populations approach the emerging infectious diseases [98].

From the total of 48 studies included in to this systematic review, only 19 studies were conducted among HCWs. The results of this systematic review showed that there was a substantial discrepancy on the level of attitude towards COVID-19 vaccine among HCWs and non-HCWs globally. The level of positive attitude towards COVID-19 vaccine among HCWs was ranged from $21 \%$ [49] to $95 \%$ [50]. This finding demonstrates that there is a crucial problem that needs to be addressed in high priority to cease the era of the current pandemic. This is due to that HCWs are at high risk of COVID-19 [39]. This infection in HCWs would have an instant consequence on their occupation and the entire healthcare system [38].

Factors associated with the attitude towards COVID-19 vaccine among HCWs were age $[56,58,59,64,65,67]$, gender $[59,64$, 67], race [67], work experience [64], home location [67], having no fear of injections [64], being a non-smoker [64], profession [56, 65], presence of chronic illnesses [59], Allergy [59], confidence in pharmaceutical companies [55], confidence in the management of the epidemic [55], history of taking influenza vaccine [58], vaccine recommendation [58, 60], perceived risk of new vaccines [58], perceived utility of vaccine [58], receiving a seasonal flu vaccination in the last 5 years [60], working in a private hospital [60], a high perceived pandemic risk index [50], low vaccine harm index [50], high pro-socialness index [50], using Facebook as main information source about antiSARS-CoV-2 vaccination [65], being in close contact with a high-risk group [65], having undertaken seasonal flu vaccine during the 2019-2020 season [65], role within the hospital [67], knowledge about the virus [67], confidence in and expectations about personal protective equipment and behaviors [67].

Concerning to non-HCWs, the level of positive attitude towards COVID-19 vaccine among non-HCWs was ranged from 21.4\% [53] to $91.99 \%$ [54]. Factors associated with the attitude towards COVID-19 vaccine among non-HCWs were age [70, $71,77,78,88,91]$, gender [53, 70, 73, 77, 78, 80, 87, 90], educational level [70, 90], occupation [70, 87], marital status [53, 90], residency [74, 90], income [77, 78], ethnicity [78], risk for severe course of COVID-19 [70], direct contact with COVID-19 at work [70], being a health profession [71, 80], being vaccinated against seasonal flu [70, 71, 90], perceived benefits [71], cues to actions [71], having previous history vaccination [73], fear of passing on the disease to relatives [54], and the year of medical study [54], studying health-related courses [74], COVID-19 concern [77], adherence level to social distancing guidelines [78], history of chronic disease [87], being pregnancy [87], perceived vaccine safety [91], having a close acquaintance who did not experience a vaccine-related adverse reaction [88], having more information about vaccine effectiveness [88], mandatory vaccination [88], being recommended to be vaccinated [88], lack of the confidence in the healthcare system to control epidemic [90], heard about COVID-19 vaccines [91], believe in COVID-19 vaccines protection from COVID-19 infection [91], those who encouraged their family members and friends to get vaccinated [91]. 
Generally, the findings of this systematic review showed that several factors have been associated with the attitude towards COVID-19 vaccine among both HCWs and non-HCWs. This is because of that even though the immunization coverage is described administratively across the world, no likewise vigorous monitoring system occurs for vaccine confidence. There is rising evidence of vaccine denial because of the lack of trust in the benefits, safety, and effectiveness of vaccines [99]. The acceptance of a COVID-19 vaccine was vastly affected by the effectiveness of the vaccine [100]. Besides, if people lack enough knowledge towards the vaccine, this might lead to negative attitudes about it, which will avoid it to accept the vaccine. If communication efforts fail to address vaccine-negative persons', the liberty-associated concerns may not be successful [101]. Even, the political talk was found to have a significant effect on the attitudes of individuals. For instance; this study showed that political talk plays a considerable role in shaping and polarizing attitudes on stem cell research [102]. The intention to accept this vaccine maybe affected by online misinformation, it is significantly associated with failures in vaccination intent [96]. Furthermore, vaccine-related conspiracy theories could affect the attitude of individuals towards the vaccine. This is supported by the experimental study conducted in China [103]. Moreover, according to the planned behavior theory, attitudes regarding to behavior, subjective norms of behavior, and perceived control over behavior forecast behavioral willingness, while this willingness together with perceived behavioral control accounts for a substantial proportion of variance in behavior [104]. Finally, even though, it is expected that the attitude towards COVID-19 vaccine among HCWs will be greater than that of non-HCWs, the findings of this systematic review indicated that the level of positive attitude towards COVID-19 vaccine among HCWs and non-HCWs was comparable.

\section{Recommendations}

The acceptance of vaccines against COVID-19 is a vital to fight this pandemic [105]. Hence, to rise the vaccination, considering the psychological science of action is suggested. It can be applied through; thoughts and feelings, social processes, and interventions can facilitate vaccination [95]. From the theory of normative conduct, norms have a substantial role in shaping human behavior. Thus, to improve the probability of socially beneficial behavior in others via norm activation would be well advised [106]. Vaccinations against COVID-19 pandemic might be a significant element of public health and fighting anti-vaccination attitudes may assist this efforts [107]. Preventing the attack on science, trust in scientists, and using nonconservative media for the better perception of COVID-19 vaccine is advised. The use of nonconservative media would rise the trust in scientists, whereas this would rise the certainty that COVID-19 vaccine could be a good solution for this pandemic. This is supported by the study conducted in United states of America [108]. Considering the power and impact of media usage on social trust and risk perception, more efforts are required to confirm a correct and balanced information is being spread, while the social media in particular [109]. Social norms and family discussion might be fundamental in qualifying the community for the acceptance of COVID-19 vaccine. This is supported by the study done among Asian Americans in United states of America [110]. The coupled monitoring vaccine attitudes and vaccination rates at the nationwide and subnational levels could support in identifying individuals with diminishing confidence and acceptance towards the vaccine [111]. Applying the protection motivation theory is also suggested for this pandemic. This is because, in the context of this theory, the individuals under threat would made their protection decisions and coping judgements. The more shocking the individuals danger appraisals and promising coping judgements, motivation for vaccine will be increased [112]. Lastly, since rumors and conspiracy theories may bring mistrust which contributes to vaccine hesitancy, following the misinformation regarding a COVID-19 vaccine in real-time and using social media to distribute accurate information can support to protect the population from misinformation [113]. The campaigns and messaging concerning taking the vaccine against COVID-19 should consider the risk of COVID-19 to others and the requirement for everybody to take the vaccine [114]. Evolving communication to avoid vaccine hesitancy is significant to control COVID-19. Forwarding the effective messages to the public concerning this vaccine is crucial to promote the acceptance of this vaccine [115]. Campaigns to disseminate information are also vital to promote participation in the immunization of COVID-19 pandemic [116].

\section{Conclusions}


Despite the substantial crisis made by COVID-19 pandemic worldwide, it hasn't been managed and controlled effectively. The vaccines against COVID-19 have been developed after a long wait and worldwide anxiety as the best solution for this pandemic. The acceptance of vaccines against COVID-19 is vital to fight this pandemic. According to this systematic review findings, the level of positive attitude towards COVID-19 vaccine among HCWs was ranged from $21 \%$ to $95 \%$. Age, gender, race, work experience, home location, having no fear of injections, being a non-smoker, profession, presence of chronic illnesses, allergies, confidence in pharmaceutical companies, confidence in the management of the epidemic, history of taking influenza vaccine, vaccine recommendation, perceived risk of new vaccines, perceived utility of vaccine, receiving a seasonal flu vaccination in the last 5 years, working in a private hospital, a high perceived pandemic risk index, low vaccine harm index, high pro-socialness index, using Facebook as main information source about antiSARS-CoV-2 vaccination, being in close contact with a high-risk group, having undertaken seasonal flu vaccine during the 2019-2020 season, role within the hospital, knowledge about the virus, confidence in and expectations about personal protective equipment and behaviors were factors significantly associated with the attitude towards COVID-19 vaccine among HCWs.

The level of positive attitude towards COVID-19 vaccine among non-HCWs was ranged from $21.4 \%$ to $91.99 \%$. Factors associated with the attitude towards COVID-19 vaccine among non-HCWs were age, gender, educational level, occupation, marital status, residency, income, ethnicity, risk for severe course of COVID-19, direct contact with COVID-19 at work, being a health profession, being vaccinated against seasonal flu, perceived benefits, cues to actions, having previous history of vaccination, fear of passing on the disease to relatives, and the year of medical study, studying health-related courses, COVID-19 concern, adherence level to social distancing guidelines, history of chronic disease, being pregnancy, perceived vaccine safety, having a close acquaintance who did not experience a vaccine-related adverse reaction, having more information about vaccine effectiveness, mandatory vaccination, being recommended to be vaccinated, lack of the confidence in the healthcare system to control epidemic, heard about COVID-19 vaccines, believe in COVID-19 vaccines protection from COVID-19 infection, those who encouraged their family members and friends to get vaccinated.

Lastly, the levels of positive attitude towards COVID-19 vaccine among both HCWs and non-HCWs were unfavorable and comparable. The unfavorable attitude regarding COVID-19 vaccine among both HCWs, and non- HCWs would significantly reduce the role of vaccination in dropping the burden of the COVID-19 pandemic throughout the community. Globally, there is a need for call for action to cease the time and the associated crisis of this pandemic. This is because HCWs are the major source of health-related information for their communities. Thus, we need to equip them with the most truthful and reliable knowledge to improve their attitude towards COVID-19 vaccine.

\section{Abbreviations}

COVID-19; Coronavirus disease 2019, HCWs; healthcare workers, non-HCWs; nonhealthcare worker, PRISMA; Preferred Reporting Items for Systematic reviews and Meta-Analyses, US; United States, NOS; Newcastle-Ottawa Scale.

\section{Declarations}

\section{Consent for Publication}

Not applicable.

\section{Availability of Data and Materials}

The data used to support the findings of this study are included in the manuscript.

\section{Competing Interest}


The author declares no conflicts of interest for this work.

\section{Author Contributions}

The author has contributed to the conception of the study, drafting or revising the article, writing the manuscript, gave final approval of the version to be published, and agreed to be accountable for all aspects of the work.

\section{Acknowledgments}

Not applicable.

\section{Funding}

None.

\section{References}

1. The Impact of COVID-19 on Children in West and Central Africa: Learning from 2020; Save the children. Resource Centre. https://resourcecentre.savethechildren.net/node/18647/pdf/rapport_covid_anglais.pdf. Accessed 18 Jun 2021.

2. Mannan KA, Farhana KM. Knowledge, Attitude and Acceptance of a COVID-19 Vaccine: A Global Cross-Sectional Study. SSRN Electron J. 2020. doi:10.2139/ssrn.3763373.

3. Lotfi M, Hamblin MR, Rezaei N. COVID-19: Transmission, prevention, and potential therapeutic opportunities. Clin Chim Acta. 2020;508:254-66. doi:10.1016/j.cca.2020.05.044.

4. Jin Y, Yang H, Ji W, Wu W, Chen S, Zhang W, et al. Virology, Epidemiology, Pathogenesis, and Control of COVID-19. Viruses. 2020;12:372. doi:10.3390/v12040372.

5. Wang L, Wang Y, Ye D, Liu Q. Review of the 2019 novel coronavirus (SARS-CoV-2) based on current evidence. Int J Antimicrob Agents. 2020;55:105948. doi:10.1016/j.ijantimicag.2020.105948.

6. Shanafelt T, Ripp J, Trockel M. Understanding and Addressing Sources of Anxiety Among Health Care Professionals During the COVID-19 Pandemic. JAMA. 2020;323:2133. doi:10.1001/jama.2020.5893.

7. Dariya B, Nagaraju GP. Understanding novel COVID-19: Its impact on organ failure and risk assessment for diabetic and cancer patients. Cytokine Growth Factor Rev. 2020;53:43-52. doi:10.1016/j.cytogfr.2020.05.001.

8. Lu Q, Shi Y. Coronavirus disease (COVID-19) and neonate: What neonatologist need to know. J Med Virol. 2020;92:564-7. doi:10.1002/jmv.25740.

9. Ataguba JE. COVID-19 Pandemic, a War to be Won: Understanding its Economic Implications for Africa. Appl Health Econ Health Policy. 2020;18:325-8. doi:10.1007/s40258-020-00580-x.

10. Gadermann AC, Thomson KC, Richardson CG, Gagné M, McAuliffe C, Hirani S, et al. Examining the impacts of the COVID19 pandemic on family mental health in Canada: findings from a national cross-sectional study. BMJ Open. 2021;11:e042871. doi:10.1136/bmjopen-2020-042871.

11. Kajdy A, Feduniw S, Ajdacka U, Modzelewski J, Baranowska B, Sys D, et al. Risk factors for anxiety and depression among pregnant women during the COVID-19 pandemic: A web-based cross-sectional survey. Medicine (Baltimore). 
12. Liang L, Ren H, Cao R, Hu Y, Qin Z, Li C, et al. The Effect of COVID-19 on Youth Mental Health. Psychiatr Q. 2020. doi:10.1007/s11126-020-09744-3.

13. Yoshikawa H, Wuermli AJ, Britto PR, Dreyer B, Leckman JF, Lye SJ, et al. Effects of the Global Coronavirus Disease-2019 Pandemic on Early Childhood Development: Short- and Long-Term Risks and Mitigating Program and Policy Actions. J Pediatr. 2020;223:188-93. doi:10.1016/j.jpeds.2020.05.020.

14. Fahriani M, Anwar S, Yufika A, Bakhtiar B, Wardani E, Winardi W, et al. Disruption of childhood vaccination during the COVID-19 pandemic in Indonesia. Narra J. 2021;1. doi:10.52225/narraj.v1i1.7.

15. Deprest J, Choolani M, Chervenak F, Farmer D, Lagrou K, Lopriore E, et al. Fetal Diagnosis and Therapy during the COVID19 Pandemic: Guidance on Behalf of the International Fetal Medicine and Surgery Society. Fetal Diagn Ther. 2020;:1-10. doi:10.1159/000508254.

16. Nachega JB, Kapata N, Sam-Agudu NA, Decloedt EH, Katoto PDMC, Nagu T, et al. Minimizing the impact of the triple burden of COVID-19, tuberculosis and HIV on health services in sub-Saharan Africa. Int J Infect Dis. 2021;0. doi:10.1016/j.jijid.2021.03.038.

17. Ogunbiyi O. The disproportionate burden of COVID-19 in Africa. COVID-19 Pandemic. 2022;:179-87. doi:10.1016/B978-0323-82860-4.00021-5.

18. Dashraath P, Wong JLJ, Lim MXK, Lim LM, Li S, Biswas A, et al. Coronavirus disease 2019 (COVID-19) pandemic and pregnancy. Am J Obstet Gynecol. 2020;222:521-31. doi:10.1016/j.ajog.2020.03.021.

19. Borriello A, Master D, Pellegrini A, Rose JM. Preferences for a COVID-19 vaccine in Australia. Vaccine. 2021;39:473-9. doi:10.1016/j.vaccine.2020.12.032.

20. Lazarus JV, Ratzan SC, Palayew A, Gostin LO, Larson HJ, Rabin K, et al. A global survey of potential acceptance of a COVID-19 vaccine. Nat Med. 2021;27:225-8. doi:10.1038/s41591-020-1124-9.

21. Hursh SR, Strickland JC, Schwartz LP, Reed DD. Quantifying the Impact of Public Perceptions on Vaccine Acceptance Using Behavioral Economics. Front Public Health. 2020;8. doi:10.3389/fpubh.2020.608852.

22. Alley SJ, Stanton R, Browne M, To QG, Khalesi S, Williams SL, et al. As the Pandemic Progresses, How Does Willingness to Vaccinate against COVID-19 Evolve? Int J Environ Res Public Health. 2021;18. doi:10.3390/ijerph18020797.

23. Palamenghi L, Barello S, Boccia S, Graffigna G. Mistrust in biomedical research and vaccine hesitancy: the forefront challenge in the battle against COVID-19 in Italy. Eur J Epidemiol. 2020;35:785-8. doi:10.1007/s10654-020-00675-8.

24. Daly M, Robinson E. Willingness to vaccinate against COVID-19 in the US: Longitudinal evidence from a nationally representative sample of adults from April-October 2020. medRxiv. 2020. doi:10.1101/2020.11.27.20239970.

25. Graffigna G, Palamenghi L, Boccia S, Barello S. Relationship between Citizens' Health Engagement and Intention to Take the COVID-19 Vaccine in Italy: A Mediation Analysis. Vaccines. 2020;8:576. doi:10.3390/vaccines8040576.

26. Bell S, Clarke R, Mounier-Jack S, Walker JL, Paterson P. Parents' and guardians' views on the acceptability of a future COVID-19 vaccine: A multi-methods study in England. Vaccine. 2020;38:7789-98. doi:10.1016/j.vaccine.2020.10.027.

27. Goldman RD, Yan TD, Seiler M, Parra Cotanda C, Brown JC, Klein EJ, et al. Caregiver willingness to vaccinate their children against COVID-19: Cross sectional survey. Vaccine. 2020;38:7668-73. doi:10.1016/j.vaccine.2020.09.084. 
28. Goldman RD, Staubli G, Cotanda CP, Brown JC, Hoeffe J, Seiler M, et al. Factors associated with parents' willingness to enroll their children in trials for COVID-19 vaccination. Hum Vaccines Immunother. 2021;17:1607-11. doi:10.1080/21645515.2020.1834325.

29. Marcec R, Majta M, Likic R. Will vaccination refusal prolong the war on SARS-CoV-2? Postgrad Med J. 2021;97:143-9. doi:10.1136/postgradmedj-2020-138903.

30. Qiao S, Tam CC, Li X. Risk exposures, risk perceptions, negative attitudes toward general vaccination, and COVID-19 vaccine acceptance among college students in South Carolina. preprint. Infectious Diseases (except HIV/AIDS); 2020. doi:10.1101/2020.11.26.20239483.

31. Neumann-Böhme S, Varghese NE, Sabat I, Barros PP, Brouwer W, van Exel J, et al. Once we have it, will we use it? A European survey on willingness to be vaccinated against COVID-19. Eur J Health Econ. 2020;21:977-82. doi:10.1007/s10198-020-01208-6.

32. Kuppalli K, Brett-Major DM, Smith TC. COVID-19 Vaccine Acceptance: We Need to Start Now. Open Forum Infect Dis. 2021;8:ofaa658. doi:10.1093/ofid/ofaa658.

33. Küçükkarapınar M, Karadağ R, Budakoğlu I, Aslan S, Uçar S, Yay A. COVID-19 Vaccine Hesitancy and Its Relationship With Illness Risk Perceptions, Affect, Worry, and Public Trust: An Online Serial Cross-Sectional Survey From Turkey. Psychiatry Clin Psychopharmacol. 2021;31:98-109. doi:10.5152/pcp.2021.21017.

34. Ngoyi JM, Mbuyu LK, Kibwe DN, Kabamba LN, Umba EK, Tambwe PN, et al. Covid-19 vaccination acceptance among students of the Higher Institute of Medical Techniques of Lubumbashi, Democratic Republic of Congo. Rev L'Infirmier Congo. 2020;4:48-52. https://www.revue.istmlubumbashi.net/wp-content/uploads/2021/02/Covid-19-vaccination-acceptanceamong-students-of-the-Higher-Institute-of-Medical.pdf.

35. Maroudy D. [Vaccination of healthcare workers against COVID-19]. Soins Rev Ref Infirm. 2021;66:10-3. doi:10.1016/S0038-0814(21)00120-1.

36. Pean De Ponfilly G, Pilmis B, El Kaibi I, Castreau N, Laplanche S, Le Monnier A. Is the second dose of vaccination useful in previously SARS-CoV-2-infected healthcare workers? Infect Dis Now. 2021;:S2666-9919(21)00424-3.

37. Rodríguez J, Patón M, Acuña JM. COVID-19 vaccination rate and protection attitudes can determine the best prioritisation strategy to reduce fatalities. medRxiv. 2021. doi:10.1101/2020.10.12.20211094.

38. Amit S, Beni SA, Biber A, Grinberg A, Leshem E, Regev-Yochay G. Postvaccination COVID-19 among Healthcare Workers, Israel. Emerg Infect Dis. 2021;27:1220-2. doi:10.3201/eid2704.210016.

39. Kamacooko O, Kitonsa J, Bahemuka UM, Kibengo FM, Wajja A, Basajja V, et al. Knowledge, Attitudes, and Practices Regarding COVID-19 among Healthcare Workers in Uganda: A Cross-Sectional Survey. Int J Environ Res Public Health. 2021;18:7004.

40. Thaker J. Planning for a COVID-19 Vaccination Campaign: The Role of Social Norms, Trust, Knowledge, and Vaccine Attitudes. 2020. doi:10.31234/osf.io/q8mz6.

41. Mateo-Urdiales A, Del Manso M, Andrianou X, Spuri M, D’Ancona F, Filia A, et al. Initial impact of SARS-Cov-2 vaccination on healthcare workers in Italy- Update on the 28th of March 2021. Vaccine. 2021. doi:10.1016/j.vaccine.2021.07.003.

42. Modesti PA, Reboldi G, Cappuccio FP, Agyemang C, Remuzzi G, Rapi S, et al. Panethnic Differences in Blood Pressure in Europe: A Systematic Review and Meta-Analysis. PLOS ONE. 2016;11:e0147601. doi:10.1371/journal.pone.0147601. 
43. GA Wells, B Shea, D O'Connell, J Peterson, V Welch, M Losos, et al. The Newcastle-Ottawa Scale (NOS) for Assessing the Quality of Nonrandomized Studies in Meta-Analyses, Ottawa Hospital Research Institute, Ottawa, Canada. http://www.ohri.ca/programs/clinical_epidemiology/oxford.asp. Accessed 21 May 2021.

44. Yazew KG, Walle TA, Azagew AW. Prevalence of anti-diabetic medication adherence and determinant factors in Ethiopia: A systemic review and meta-analysis, 2019. Int J Afr Nurs Sci. 2019;11:100167. doi:10.1016/j.ijans.2019.100167.

45. Liberati A, Altman DG, Tetzlaff J, Mulrow C, Gotzsche PC, loannidis JPA, et al. The PRISMA statement for reporting systematic reviews and meta-analyses of studies that evaluate healthcare interventions: explanation and elaboration. BMJ. 2009;339 jul21 1:b2700-b2700. doi:10.1136/bmj.b2700.

46. Moher D, Liberati A, Tetzlaff J, Altman DG. Preferred Reporting Items for Systematic Reviews and Meta-Analyses: The PRISMA Statement. J Clin Epidemiol. 2009;62:1006-12. doi:10.1016/j.jclinepi.2009.06.005.

47. Harsch IA, Ortloff A, Reinhöfer M, Epstude J. Symptoms, antibody levels and vaccination attitude after asymptomatic to moderate COVID-19 infection in 200 healthcare workers. GMS Hyg Infect Control. 2021;16:Doc15. doi:10.3205/dgkh000386.

48. Shaw J, Stewart T, Anderson KB, Hanley S, Thomas SJ, Salmon DA, et al. Assessment of U.S. health care personnel (HCP) attitudes towards COVID-19 vaccination in a large university health care system. Clin Infect Dis Off Publ Infect Dis Soc Am. 2021;:ciab054. doi:10.1093/cid/ciab054.

49. Fares S, Elmnyer MM, Mohamed SS, Elsayed R. COVID-19 Vaccination Perception and Attitude among Healthcare Workers in Egypt. J Prim Care Community Health. 2021;12:21501327211013304. doi:10.1177/21501327211013303.

50. Chew NWS, Cheong C, Kong G, Phua K, Ngiam JN, Tan BYQ, et al. An Asia-Pacific study on healthcare workers' perceptions of, and willingness to receive, the COVID-19 vaccination. Int J Infect Dis. 2021;106:52-60. doi:10.1016/j.jijid.2021.03.069.

51. Kuhn R, Henwood B, Lawton A, Kleva M, Murali K, King C, et al. COVID-19 vaccine access and attitudes among people experiencing homelessness from pilot mobile phone survey in Los Angeles, CA. medRxiv. 2021;:2021.03.23.21254146. doi:10.1101/2021.03.23.21254146.

52. Paul E, Steptoe A, Fancourt D. Attitudes towards vaccines and intention to vaccinate against COVID-19: Implications for public health communications. Lancet Reg Health - Eur. 2021;1:100012. doi:10.1016/j.lanepe.2020.100012.

53. Kasrine Al Halabi C, Obeid S, Sacre H, Akel M, Hallit R, Salameh P, et al. Attitudes of Lebanese adults regarding COVID-19 vaccination. BMC Public Health. 2021;21:998. doi:10.1186/s12889-021-10902-w.

54. Szmyd B, Bartoszek A, Karuga FF, Staniecka K, Błaszczyk M, Radek M. Medical Students and SARS-CoV-2 Vaccination: Attitude and Behaviors. Vaccines. 2021;9:128. doi:10.3390/vaccines9020128.

55. Vignier N, Brureau K, Granier S, Breton J, Michaud C, Gaillet M, et al. Attitudes towards the COVID-19 Vaccine and Willingness to Get Vaccinated among Healthcare Workers in French Guiana: The Influence of Geographical Origin. Vaccines. 2021;9:682. doi:10.3390/vaccines9060682.

56. Alle YF, Oumer KE. Attitude and associated factors of COVID-19 vaccine acceptance among health professionals in Debre Tabor Comprehensive Specialized Hospital, North Central Ethiopia; 2021: cross-sectional study. VirusDisease. 2021. doi:10.1007/s13337-021-00708-0.

57. Kaur A, Kaur G, Kashyap A, Singh G, Singh Sandhu H, Khilji I, et al. Attitude and acceptance of Covid-19 vaccine amongst medical and dental fraternity - a questionnaire survey. Rocz Panstw Zakl Hig. 2021;72:185-91.

doi:10.32394/rpzh.2021.0162.

Page $12 / 22$ 
58. Verger P, Scronias D, Dauby N, Adedzi KA, Gobert C, Bergeat M, et al. Attitudes of healthcare workers towards COVID-19 vaccination: a survey in France and French-speaking parts of Belgium and Canada, 2020. Eurosurveillance. 2021;26:2002047. doi:10.2807/1560-7917.ES.2021.26.3.2002047.

59. Ahmed G, Almoosa Z, Mohamed D, Rapal J, Minguez O, Abu Khurma I, et al. Healthcare Provider Attitudes toward the Newly Developed COVID-19 Vaccine: Cross-Sectional Study. Nurs Rep. 2021;11:187-94. doi:10.3390/nursrep11010018.

60. Fakonti G, Kyprianidou M, Toumbis G, Giannakou K. Attitudes and Acceptance of COVID-19 Vaccination Among Nurses and Midwives in Cyprus: A Cross-Sectional Survey. Front Public Health. 2021;9. doi:10.3389/fpubh.2021.656138.

61. Guangul BA, Georgescu G, Osman M, Reece R, Derso Z, Bahiru A, et al. Healthcare workers attitude towards SARS-COVID2 Vaccine, Ethiopia. Glob J Infect Dis Clin Res. 2021;7:043-8. doi:10.17352/2455-5363.000045.

62. Nasir M, Perveen RA, Saha SK, Nessa A, Zaman A, Nazneen R, et al. Vaccination against COVID-19 in Bangladesh: Perception and Attitude of Healthcare Workers in COVID-dedicated Hospitals. Mymensingh Med J MMJ. 2021;30:808-15. https://pubmed.ncbi.nlm.nih.gov/34226472/.

63. Paudel S, Palaian S, Shankar PR, Subedi N. Risk Perception and Hesitancy Toward COVID-19 Vaccination Among Healthcare Workers and Staff at a Medical College in Nepal. Risk Manag Healthc Policy. 2021;14:2253-61. doi:10.2147/RMHP.S310289.

64. Baghdadi LR, Alghaihb SG, Abuhaimed AA, Alkelabi DM, Alqahtani RS. Healthcare Workers' Perspectives on the Upcoming COVID-19 Vaccine in Terms of Their Exposure to the Influenza Vaccine in Riyadh, Saudi Arabia: A Cross-Sectional Study. Vaccines. 2021;9:465.

65. Di Gennaro F, Murri R, Segala FV, Cerruti L, Abdulle A, Saracino A, et al. Attitudes towards Anti-SARS-CoV2 Vaccination among Healthcare Workers: Results from a National Survey in Italy. Viruses. 2021;13:371. doi:10.3390/v13030371.

66. Elhadi M, Alsoufi A, Alhadi A, Hmeida A, Alshareea E, Dokali M, et al. Knowledge, attitude, and acceptance of healthcare workers and the public regarding the COVID-19 vaccine: a cross-sectional study. BMC Public Health. 2021;21:1-21. doi:10.1186/s12889-021-10987-3.

67. Ciardi F, Menon V, Jensen JL, Shariff MA, Pillai A, Venugopal U, et al. Knowledge, Attitudes and Perceptions of COVID-19 Vaccination among Healthcare Workers of an Inner-City Hospital in New York. Vaccines. 2021;9:516. doi:10.3390/vaccines9050516.

68. Szmyd B, Karuga FF, Bartoszek A, Staniecka K, Siwecka N, Bartoszek A, et al. Attitude and Behaviors towards SARS-CoV-2 Vaccination among Healthcare Workers: A Cross-Sectional Study from Poland. Vaccines. 2021;9:218.

69. Ledda C, Costantino C, Cuccia M, Maltezou HC, Rapisarda V. Attitudes of Healthcare Personnel towards Vaccinations before and during the COVID-19 Pandemic. Int J Environ Res Public Health. 2021;18:2703. doi:10.3390/ijerph18052703.

70. Bauernfeind S, Hitzenbichler F, Huppertz G, Zeman F, Koller M, Schmidt B, et al. Brief report: attitudes towards Covid-19 vaccination among hospital employees in a tertiary care university hospital in Germany in December 2020. Infection. 2021. doi:10.1007/s15010-021-01622-9.

71. Spinewine A, Pétein C, Evrard P, Vastrade C, Laurent C, Delaere B, et al. Attitudes towards COVID-19 Vaccination among Hospital Staff-Understanding What Matters to Hesitant People. Vaccines. 2021;9:469. doi:10.3390/vaccines9050469.

72. Mesesle M. <p>Awareness and Attitude Towards COVID-19 Vaccination and Associated Factors in Ethiopia: CrossSectional Study</p>. Infect Drug Resist. 2021;14:2193-9. doi:10.2147/IDR.S316461. 
73. Islam MS, Siddique AB, Akter R, Tasnim R, Sujan MSH, Ward PR, et al. Knowledge, attitudes and perceptions towards COVID-19 vaccinations: a cross-sectional community survey in Bangladesh. medRxiv. 2021;:2021.02.16.21251802. doi:10.1101/2021.02.16.21251802.

74. Bai W, Cai H, Liu S, Liu H, Qi H, Chen X, et al. Attitudes toward COVID-19 vaccines in Chinese college students. Int J Biol Sci. 2021;17:1469-75. doi:10.7150/ijbs.58835.

75. Brodziak A, Sigorski D, Osmola M, Wilk M, Gawlik-Urban A, Kiszka J, et al. Attitudes of Patients with Cancer towards Vaccinations-Results of Online Survey with Special Focus on the Vaccination against COVID-19. Vaccines. 2021;9:411. doi:10.3390/vaccines9050411.

76. Akarsu B, Özdemir DC, Baser DA, Aksoy H, Fidancı İ, Cankurtaran M. While studies on COVID-19 vaccine is ongoing, the public's thoughts and attitudes to the future COVID-19 vaccine. Int J Clin Pract. 2021;75:e13891. doi:10.1111/ijcp.13891.

77. Ward JK, Alleaume C, Peretti-Watel P, Peretti-Watel P, Seror V, Cortaredona S, et al. The French public's attitudes to a future COVID-19 vaccine: The politicization of a public health issue. Soc Sci Med. 2020;265:113414. doi:10.1016/j.socscimed.2020.113414.

78. Freeman D, Loe BS, Chadwick A, Vaccari C, Waite F, Rosebrock L, et al. COVID-19 vaccine hesitancy in the UK: the Oxford coronavirus explanations, attitudes, and narratives survey (Oceans) II. Psychol Med. 2021;:1-15. doi:10.1017/S0033291720005188.

79. Pogue K, Jensen JL, Stancil CK, Ferguson DG, Hughes SJ, Mello EJ, et al. Influences on Attitudes Regarding Potential COVID-19 Vaccination in the United States. Vaccines. 2020;8:582. doi:10.3390/vaccines8040582.

80. Cordina M, Lauri MA, Lauri. J, Cordina M, Lauri MA, Lauri. J. Attitudes towards COVID-19 vaccination, vaccine hesitancy and intention to take the vaccine. Pharm Pract Granada. 2021;19. doi:10.18549/pharmpract.2021.1.2317.

81. Alabdulla M, Reagu SM, Al-Khal A, Elzain M, Jones RM. COVID-19 vaccine hesitancy and attitudes in Qatar: A national cross-sectional survey of a migrant-majority population. Influenza Other Respir Viruses. 2021;15:361-70. doi:10.1111/irv.12847.

82. Chen M, Li Y, Chen J, Wen Z, Feng F, Zou H, et al. An online survey of the attitude and willingness of Chinese adults to receive COVID-19 vaccination. Hum Vaccines Immunother. 2021;17:2279-88.

83. La Vecchia C, Negri E, Alicandro G, Scarpino V. Attitudes towards influenza vaccine and a potential COVID-19 vaccine in Italy and differences across occupational groups, September 2020. Med Lav. 2020;111:445-8. doi:10.23749/mdl.v111i6.10813.

84. Largent EA, Persad G, Sangenito S, Glickman A, Boyle C, Emanuel EJ. US Public Attitudes Toward COVID-19 Vaccine Mandates. JAMA Netw Open. 2020;3:e2033324-e2033324. doi:10.1001/jamanetworkopen.2020.33324.

85. El-Elimat T, AbuAISamen MM, Almomani BA, Al-Sawalha NA, Alali FQ. Acceptance and attitudes toward COVID-19 vaccines: A cross-sectional study from Jordan. PLOS ONE. 2021;16:e0250555. doi:10.1371/journal.pone.0250555.

86. Graeber D, Schmidt-Petri C, Schröder C. Attitudes on voluntary and mandatory vaccination against COVID-19: Evidence from Germany. PLOS ONE. 2021;16:e0248372. doi:10.1371/journal.pone.0248372.

87. Al-Marshoudi S, Al-Balushi H, Al-Wahaibi A, Al-Khalili S, Al-Maani A, Al-Farsi N, et al. Knowledge, Attitudes, and Practices (KAP) toward the COVID-19 Vaccine in Oman: A Pre-Campaign Cross-Sectional Study. Vaccines. 2021;9:602.

doi:10.3390/vaccines9060602.

Page 14/ 22 
88. Villarreal-Garza C, Vaca-Cartagena BF, Becerril-Gaitan A, Ferrigno AS, Mesa-Chavez F, Platas A, et al. Attitudes and Factors Associated With COVID-19 Vaccine Hesitancy Among Patients With Breast Cancer. JAMA Oncol. 2021. doi:10.1001/jamaoncol.2021.1962.

89. Jiang N, Wei B, Lin H, Wang Y, Chai S, Liu W. Nursing students' attitudes, knowledge, and willingness to receive the COVID19 vaccine: A cross-sectional study. medRxiv. 2021;:2021.05.24.21257710. doi:10.1101/2021.05.24.21257710.

90. Omar DI, Hani BM. Attitudes and intentions towards COVID-19 vaccines and associated factors among Egyptian adults. J Infect Public Health. 2021. doi:10.1016/j.jiph.2021.06.019.

91. Cai H, Bai W, Liu S, Liu H, Chen X, Qi H, et al. Attitudes Toward COVID-19 Vaccines in Chinese Adolescents. Front Med. 2021;8. doi:10.3389/fmed.2021.691079.

92. Petravić L, Arh R, Gabrovec T, Jazbec L, Rupčić N, Starešinič N, et al. Factors Affecting Attitudes towards COVID-19 Vaccination: An Online Survey in Slovenia. Vaccines. 2021;9:247. doi:10.3390/vaccines9030247.

93. Kumari A, Ranjan P, Chopra S, Kaur D, Kaur T, Upadhyay AD, et al. Knowledge, barriers and facilitators regarding COVID-19 vaccine and vaccination programme among the general population: A cross-sectional survey from one thousand two hundred and forty-nine participants. Diabetes Metab Syndr. 2021;15:987-92. doi:10.1016/j.dsx.2021.04.015.

94. Babicki M, Mastalerz-Migas A. Attitudes toward Vaccination against COVID-19 in Poland. A Longitudinal Study Performed before and Two Months after the Commencement of the Population Vaccination Programme in Poland. Vaccines. 2021;9:503. doi:10.3390/vaccines9050503.

95. Brewer NT, Chapman GB, Rothman AJ, Leask J, Kempe A. Increasing Vaccination: Putting Psychological Science Into Action. Psychol Sci Public Interest. 2017;18:149-207. doi:10.1177/1529100618760521.

96. Loomba S, de Figueiredo A, Piatek SJ, de Graaf K, Larson HJ. Measuring the impact of COVID-19 vaccine misinformation on vaccination intent in the UK and USA. Nat Hum Behav. 2021;5:337-48. doi:10.1038/s41562-021-01056-1.

97. Al-Jayyousi GF, Sherbash MAM, Ali LAM, El-Heneidy A, Alhussaini NWZ, Elhassan MEA, et al. Factors Influencing Public Attitudes towards COVID-19 Vaccination: A Scoping Review Informed by the Socio-Ecological Model. Vaccines. 2021;9:548. doi:10.3390/vaccines9060548.

98. Southwell BG, Kelly BJ, Bann CM, Squiers LB, Ray SE, McCormack LA. Mental Models of Infectious Diseases and Public Understanding of COVID-19 Prevention. Health Commun. 2020;35:1707-10. doi:10.1080/10410236.2020.1837462.

99. de Figueiredo A, Simas C, Karafillakis E, Paterson P, Larson HJ. Mapping global trends in vaccine confidence and investigating barriers to vaccine uptake: a large-scale retrospective temporal modelling study. The Lancet. 2020;396:898908. doi:10.1016/S0140-6736(20)31558-0.

100. Harapan H, Wagner AL, Yufika A, Winardi W, Anwar S, Gan AK, et al. Acceptance of a COVID-19 Vaccine in Southeast Asia: A Cross-Sectional Study in Indonesia. Front Public Health. 2020;8:381. doi:10.3389/fpubh.2020.00381.

101. Krishna A. Poison or Prevention? Understanding the Linkages between Vaccine-Negative Individuals' Knowledge Deficiency, Motivations, and Active Communication Behaviors. Health Commun. 2018;33:1088-96.

doi:10.1080/10410236.2017.1331307.

102. Binder AR, Dalrymple KE, Brossard D, Scheufele DA. The Soul of a Polarized Democracy: Testing Theoretical Linkages Between Talk and Attitude Extremity During the 2004 Presidential Election. Commun Res. 2009;36:315-40.

doi:10.1177/0093650209333023.

Page 15/22 
103. Chen L, Zhang Y, Young R, Wu X, Zhu G. Effects of Vaccine-related Conspiracy Theories on Chinese Young Adults' Perceptions of the HPV Vaccine: An Experimental Study. Health Commun. 2020;:1-11.

doi:10.1080/10410236.2020.1751384.

104. Ajzen I. The theory of planned behavior. Organ Behav Hum Decis Process. 1991;50:179-211. doi:10.1016/07495978(91)90020-T.

105. Sethi S, Kumar A, Mandal A, Shaikh M, Hall CA, Kirk JMW, et al. The UPTAKE study: a cross-sectional survey examining the insights and beliefs of the UK population on COVID-19 vaccine uptake and hesitancy. BMJ Open. 2021;11:e048856. doi:10.1136/bmjopen-2021-048856.

106. Cialdini RB, Kallgren CA, Reno RR. A Focus Theory of Normative Conduct: A Theoretical Refinement and Reevaluation of the Role of Norms in Human Behavior. In: Advances in Experimental Social Psychology. Elsevier; 1991. p. 201-34. doi:10.1016/S0065-2601(08)60330-5.

107. Huynh HP, Senger AR. A little shot of humility: Intellectual humility predicts vaccination attitudes and intention to vaccinate against COVID-19. J Appl Soc Psychol. 2021;51:449-60. doi:10.1111/jasp.12747.

108. Hmielowski JD, Feldman L, Myers TA, Leiserowitz A, Maibach E. An attack on science? Media use, trust in scientists, and perceptions of global warming. Public Underst Sci. 2014;23:866-83. doi:10.1177/0963662513480091.

109. Liu Z, Yang JZ. In the Wake of Scandals: How Media Use and Social Trust Influence Risk Perception and Vaccination Intention among Chinese Parents. Health Commun. 2020;:1-12. doi:10.1080/10410236.2020.1748834.

110. Juon H-S, Rimal RN, Klassen A, Lee S. Social Norm, Family Communication, and HBV Screening among Asian Americans. J Health Commun. 2017;22:981-9. doi:10.1080/10810730.2017.1388454.

111. Larson HJ, de Figueiredo A, Xiahong Z, Schulz WS, Verger P, Johnston IG, et al. The State of Vaccine Confidence 2016 : Global Insights Through a 67-Country Survey. EBioMedicine. 2016;12:295-301. doi:10.1016/j.ebiom.2016.08.042.

112. Schulz PJ, Hartung U. Unsusceptible to Social Communication? The Fixture of the Factors Predicting Decisions on Different Vaccinations. Health Commun. 2020;:1-9. doi:10.1080/10410236.2020.1771119.

113. Islam MS, Kamal A-HM, Kabir A, Southern DL, Khan SH, Hasan SMM, et al. COVID-19 vaccine rumors and conspiracy theories: The need for cognitive inoculation against misinformation to improve vaccine adherence. PloS One. 2021;16:e0251605.

114. Sherman SM, Smith LE, Sim J, Amlôt R, Cutts M, Dasch H, et al. COVID-19 vaccination intention in the UK: results from the COVID-19 vaccination acceptability study (CoVAccS), a nationally representative cross-sectional survey. Hum Vaccines Immunother. 2021;17:1612-21. doi:10.1080/21645515.2020.1846397.

115. Palm R, Bolsen T, Kingsland JT. The Effect of Frames on COVID-19 Vaccine Resistance. Front Polit Sci. 2021;3. doi:10.3389/fpos.2021.661257.

116. Leos-Toro C, Ribeaud D, Bechtiger L, Steinhoff A, Nivette A, Murray AL, et al. Attitudes Toward COVID-19 Vaccination Among Young Adults in Zurich, Switzerland, September 2020. Int J Public Health. 2021;0. doi:10.3389/ijph.2021.643486.

\section{Tables}

Table 1: Characteristics of the studies included in the Systematic Review on the level of positive Attitude Regarding COVID-19 vaccine among HCWs and non-HCWs over different countries. 


\begin{tabular}{|c|c|c|c|c|c|c|c|c|}
\hline Authors & Year & SP & Country & Participants & SS & SD & Level & Factors \\
\hline $\begin{array}{l}\text { Vignier et } \\
\text { al. [55] }\end{array}$ & 2021 & $\begin{array}{l}\text { January } 22 \\
\text { to March 26, } \\
2021\end{array}$ & France & HCWs & 579 & CS & $65.6 \%$ & $\begin{array}{l}\text { Confidence in } \\
\text { pharmaceutical } \\
\text { companies, and } \\
\text { Confidence in the } \\
\text { management of } \\
\text { the epidemic. }\end{array}$ \\
\hline $\begin{array}{l}\text { Alle and } \\
\text { Oumer [56] }\end{array}$ & 2021 & $\begin{array}{l}\text { February } 5 \\
\text { to March 20, } \\
2021\end{array}$ & Ethiopia & $\begin{array}{l}\text { Health } \\
\text { professions }\end{array}$ & 319 & CS & $42.3 \%$ & $\begin{array}{l}\text { Age, and } \\
\text { profession. }\end{array}$ \\
\hline $\begin{array}{l}\text { Kaur et } \\
\text { al. [57] }\end{array}$ & 2021 & $\begin{array}{l}\text { Not } \\
\text { explained }\end{array}$ & India & $\begin{array}{l}\text { medical and } \\
\text { dental } \\
\text { professionals }\end{array}$ & 520 & CS & $65 \%$ & NA \\
\hline $\begin{array}{l}\text { Verger et } \\
\text { al. [58] }\end{array}$ & 2021 & $\begin{array}{l}\text { October and } \\
\text { November } \\
2020\end{array}$ & $\begin{array}{l}\text { France and } \\
\text { French } \\
\text { speaking } \\
\text { parts of } \\
\text { Belgium } \\
\text { and Canada }\end{array}$ & HCWs & 2,678 & $\mathrm{CS}$ & $48.6 \%$ & $\begin{array}{l}\text { Age, history of } \\
\text { taking influenza } \\
\text { vaccine, vaccine } \\
\text { recommendation, } \\
\text { perceived risk of } \\
\text { new vaccines, } \\
\text { and perceived } \\
\text { utility of vaccine. }\end{array}$ \\
\hline $\begin{array}{l}\text { Ahmed et } \\
\text { al. [59] }\end{array}$ & 2021 & $\begin{array}{l}\text { Not } \\
\text { explained }\end{array}$ & $\begin{array}{l}\text { Saudi } \\
\text { Arabia }\end{array}$ & $\begin{array}{l}\text { healthcare } \\
\text { providers }\end{array}$ & 236 & CS & $55.5 \%$ & $\begin{array}{l}\text { Sex, age, } \\
\text { presence of } \\
\text { chronic illnesses, } \\
\text { and allergy. }\end{array}$ \\
\hline $\begin{array}{l}\text { Fakonti et } \\
\text { al. [60] }\end{array}$ & 2021 & $\begin{array}{l}\text { December } 8 \\
\text { to } 28,2020\end{array}$ & Cyprus & $\begin{array}{l}\text { Nurses and } \\
\text { midwives }\end{array}$ & 437 & CS & $30 \%$ & $\begin{array}{l}\text { Receiving a } \\
\text { seasonal flu } \\
\text { vaccination in } \\
\text { the last } 5 \text { years, } \\
\text { recommended } \\
\text { vaccines for } \\
\text { health } \\
\text { professionals, } \\
\text { and working in a } \\
\text { private hospital. }\end{array}$ \\
\hline $\begin{array}{l}\text { Chew et } \\
\text { al. [50] }\end{array}$ & 2021 & $\begin{array}{l}\text { December } \\
12 \text { to } 21 \\
2020\end{array}$ & Asia-Pacific & HCWs & 1720 & CS & $95 \%$ & $\begin{array}{l}\text { A high perceived } \\
\text { pandemic risk } \\
\text { index, low } \\
\text { vaccine harm } \\
\text { index and high } \\
\text { pro-socialness } \\
\text { index. }\end{array}$ \\
\hline $\begin{array}{l}\text { Guangul et } \\
\text { al. [61] }\end{array}$ & 2021 & $\begin{array}{l}\text { Not } \\
\text { explained }\end{array}$ & Ethiopia & HCWs & 668 & CS & $72.2 \%$ & NA \\
\hline $\begin{array}{l}\text { Nasir et } \\
\text { al. [62] }\end{array}$ & 2021 & $\begin{array}{l}\text { In February } \\
2021\end{array}$ & Bangladesh & HCWs & 550 & CS & $70.23 \%$ & NA \\
\hline $\begin{array}{l}\text { Paudel et } \\
\text { al. [63] }\end{array}$ & 2021 & $\begin{array}{l}\text { January } 27 \\
\text { to February } \\
3,2021 .\end{array}$ & Nepal & HCWs & 266 & CS & $38.3 \%$ & NA \\
\hline $\begin{array}{l}\text { Baghdadi et } \\
\text { al. [64] }\end{array}$ & 2021 & $\begin{array}{l}\text { July to } \\
\text { September } \\
2020\end{array}$ & $\begin{array}{l}\text { Saudi } \\
\text { Arabia }\end{array}$ & HCWs & 356 & $\mathrm{CS}$ & $61.16 \%$ & $\begin{array}{l}\text { Gender, age } \\
\text { (middle aged), } \\
\text { work experience } \\
\text { (<5 years), } \\
\text { having no fear of } \\
\text { injections, and } \\
\text { being a non- } \\
\text { smoker. }\end{array}$ \\
\hline Di Gennaro & 2021 & 1 October to & Italy & HCWs & 1723 & $\mathrm{CS}$ & $67 \%$ & Being a non-MD \\
\hline
\end{tabular}

Page 17/22 
$\begin{array}{ll} & 1 \text { November } \\ & 2020\end{array}$

health

professional, using Facebook as main information source about antiSARS-CoV-2 vaccination, being a younger, age $(<30$ years), being in close contact with a high-risk group, and having undertaken seasonal flu vaccine during the 2019-2020 season.

\begin{tabular}{|c|c|c|c|c|c|c|c|}
\hline $\begin{array}{l}\text { Elhadi et } \\
\text { al. [66] }\end{array}$ & 2021 & $\begin{array}{l}\text { December } 1 \\
\text { to } 18,2020\end{array}$ & Libya & $\begin{array}{l}\text { Physicians } \\
\text { and } \\
\text { paramedic }\end{array}$ & 2215 & $\mathrm{CS}$ & $58.19 \%$ \\
\hline
\end{tabular}

$\begin{array}{lllllll}\text { Ciardi et } 2021 & \text { December New York HCWs } & 428 & \text { CS } & 64 \% & \text { Gender, age, race, }\end{array}$

al. [67] $\quad 10,2020$ to
January 5, 2021

home location role within the hospital, knowledge about the virus, and confidence in and expectations about personal protective equipment and behaviors.

\begin{tabular}{|c|c|c|c|c|c|c|c|c|}
\hline $\begin{array}{l}\text { Fares et } \\
\text { al. [49] }\end{array}$ & 2021 & $\begin{array}{l}\text { December } \\
2020 \text { to } \\
\text { January } \\
2021\end{array}$ & Egypt & HCWs & 385 & CS & $21 \%$ & NA \\
\hline $\begin{array}{l}\text { Harsch et } \\
\text { al. [47] }\end{array}$ & 2021 & $\begin{array}{l}\text { Not } \\
\text { explained }\end{array}$ & Germany & HCWs & 200 & CS & $37.5 \%$ & NA \\
\hline $\begin{array}{l}\text { Szmyd et } \\
\text { al. [68] }\end{array}$ & 2021 & $\begin{array}{l}\text { December } \\
22,2020 \text { to } \\
\text { January } 8 \\
2021\end{array}$ & Poland & HCWs & 2300 & CS & $82.95 \%$ & NA \\
\hline $\begin{array}{l}\text { Ledda et } \\
\text { al. [69] }\end{array}$ & 2021 & $\begin{array}{l}\text { September } \\
\text { to December } \\
20,2020\end{array}$ & Italy & $\begin{array}{l}\text { Healthcare } \\
\text { Personnel }\end{array}$ & 787 & CS & $75 \%$ & NA \\
\hline $\begin{array}{l}\text { Shaw et } \\
\text { al. [48] }\end{array}$ & 2021 & $\begin{array}{l}\text { November } \\
23 \text { to } \\
\text { December 5, } \\
2020\end{array}$ & US & $\begin{array}{l}\text { Healthcare } \\
\text { personnel }\end{array}$ & 5287 & CS & $57.5 \%$ & NA \\
\hline $\begin{array}{l}\text { Bauernfeind } \\
\text { et al. [70] }\end{array}$ & 2021 & $\begin{array}{l}\text { December } \\
12 \text { to } 21 \\
2020\end{array}$ & Germany & $\begin{array}{l}\text { Hospital } \\
\text { employees }\end{array}$ & 2454 & CS & $59.5 \%$ & $\begin{array}{l}\text { Age, gender, } \\
\text { educational level, } \\
\text { risk for severe } \\
\text { course of COVID- } \\
19 \text {, occupation, } \\
\text { direct contact } \\
\text { with COVID- } 19 \text { at } \\
\text { work, flu shot in } \\
\text { influenza } \\
2019 / 2020 \text {, and } \\
\text { flu shot in }\end{array}$ \\
\hline
\end{tabular}




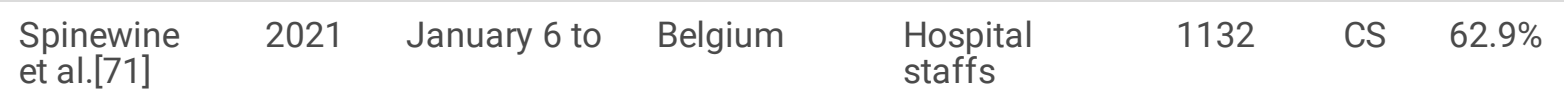

Being older, 20, 2021

physician, being vaccinated against seasonal flu, perceived benefits, and cues to actions.

\begin{tabular}{|c|c|c|c|c|c|}
\hline Mesesle [72] & 2021 & $\begin{array}{l}\text { March } 13 \text { to } \\
\text { April } 10,\end{array}$ & Ethiopia & $\begin{array}{l}\text { Adult } \\
\text { Population }\end{array}$ & 425 \\
\hline
\end{tabular}

\begin{tabular}{|c|c|c|c|c|c|c|c|c|}
\hline $\begin{array}{l}\text { Islam et } \\
\text { al [73] }\end{array}$ & 2021 & $\begin{array}{l}\text { December } \\
2020 \text { to } \\
\text { February } \\
2021\end{array}$ & Bangladesh & $\begin{array}{l}\text { Adult } \\
\text { Population }\end{array}$ & 1658 & CS & $78 \%$ & $\begin{array}{l}\text { Being female, } \\
\text { and having } \\
\text { previous history } \\
\text { vaccination. }\end{array}$ \\
\hline $\begin{array}{l}\text { Kasrine Al } \\
\text { Halabi et } \\
\text { al. [53] }\end{array}$ & 2021 & $\begin{array}{l}\text { November to } \\
\text { December } \\
2020\end{array}$ & Lebanon & $\begin{array}{l}\text { Adult } \\
\text { Population }\end{array}$ & 579 & CS & $21.4 \%$ & $\begin{array}{l}\text { Gender and } \\
\text { marital status. }\end{array}$ \\
\hline $\begin{array}{l}\text { Szmyd et al. } \\
\text { [54] }\end{array}$ & 2021 & $\begin{array}{l}\text { December } \\
22 \text { to } 25 \\
2020\end{array}$ & Poland & $\begin{array}{l}\text { Medical } \\
\text { Students }\end{array}$ & 632 & CS & $91.99 \%$ & $\begin{array}{l}\text { Fear of passing } \\
\text { on the disease to } \\
\text { relatives, and the } \\
\text { year of medical } \\
\text { study. }\end{array}$ \\
\hline $\begin{array}{l}\text { Bai et } \\
\text { al. [74] }\end{array}$ & 2021 & $\begin{array}{l}\text { December } \\
27,2020 \text { to } \\
\text { January } 18, \\
2021\end{array}$ & China & $\begin{array}{l}\text { college } \\
\text { students }\end{array}$ & 2,881 & CS & $76.3 \%$ & $\begin{array}{l}\text { Residency } \\
\text { (urban), and } \\
\text { studying health- } \\
\text { related courses. }\end{array}$ \\
\hline
\end{tabular}

\begin{tabular}{|c|c|c|c|c|c|c|c|c|}
\hline $\begin{array}{l}\text { Brodziak et } \\
\text { al. [75] }\end{array}$ & 2021 & $\begin{array}{l}\text { Not } \\
\text { explained }\end{array}$ & Poland & $\begin{array}{l}\text { Cancer } \\
\text { patients }\end{array}$ & 635 & CS & $73.7 \%$ & NA \\
\hline $\begin{array}{l}\text { Akarsu et } \\
\text { al. [76] }\end{array}$ & 2021 & $\begin{array}{l}10 / 06 / 2020 \\
\text { and } \\
10 / 07 / 2020\end{array}$ & Turkey & $\begin{array}{l}\text { Adult } \\
\text { Population }\end{array}$ & 759 & CS & $49.7 \%$ & NA \\
\hline $\begin{array}{l}\text { Ward et } \\
\text { al. [77] }\end{array}$ & 2020 & $\begin{array}{l}\text { Each week } \\
\text { of April } \\
2020\end{array}$ & France & $\begin{array}{l}\text { Adult } \\
\text { Population }\end{array}$ & 5018 & CS & $76 \%$ & $\begin{array}{l}\text { Gender, age, } \\
\text { COVID-19 } \\
\text { concern, and } \\
\text { HICU. }\end{array}$ \\
\hline $\begin{array}{l}\text { Szmyd et } \\
\text { al. [54] }\end{array}$ & 2021 & $\begin{array}{l}\text { December } \\
22 \text { to } 25 \\
2020\end{array}$ & Poland & $\begin{array}{l}\text { Nonmedical } \\
\text { Students }\end{array}$ & 763 & CS & $59.42 \%$ & NA \\
\hline $\begin{array}{l}\text { Freeman et } \\
\text { al. [78] }\end{array}$ & 2021 & $\begin{array}{l}\text { September } \\
24 \text { to } \\
\text { October } 17, \\
2020\end{array}$ & UK & $\begin{array}{l}\text { Adult } \\
\text { Population }\end{array}$ & 5,114 & CS & $71.7 \%$ & $\begin{array}{l}\text { younger age, } \\
\text { female gender, } \\
\text { lower income, } \\
\text { ethnicity, and } \\
\text { lower adherence } \\
\text { to social } \\
\text { distancing } \\
\text { guidelines. }\end{array}$ \\
\hline $\begin{array}{l}\text { Pogue et } \\
\text { al. [79] }\end{array}$ & 2020 & $\begin{array}{l}\text { Not } \\
\text { explained }\end{array}$ & $\begin{array}{l}\text { United } \\
\text { States }\end{array}$ & $\begin{array}{l}\text { Adult } \\
\text { Population }\end{array}$ & 316 & CS & $68 \%$ & NA \\
\hline $\begin{array}{l}\text { Paul et } \\
\text { al. [52] }\end{array}$ & 2021 & $\begin{array}{l}\text { March } \\
21 / 2020\end{array}$ & UK & $\begin{array}{l}\text { Adult } \\
\text { Population }\end{array}$ & 32,361 & CS & $84 \%$ & NA \\
\hline
\end{tabular}




\begin{tabular}{|c|c|c|c|c|c|c|c|c|}
\hline $\begin{array}{l}\text { Cordina et } \\
\text { al. [80] }\end{array}$ & 2021 & $\begin{array}{l}30 / 10 / 2020 \\
\text { to } \\
16 / 11 / 2020\end{array}$ & Malta & $\begin{array}{l}\text { Adult } \\
\text { Population }\end{array}$ & 2529 & CS & $50 \%$ & $\begin{array}{l}\text { Gender(male), } \\
\text { and being health } \\
\text { profession. }\end{array}$ \\
\hline $\begin{array}{l}\text { Alabdulla et } \\
\text { al.[81] }\end{array}$ & 2021 & $\begin{array}{l}\text { October } 15 \\
\text { to November } \\
15,2020\end{array}$ & Qatar & $\begin{array}{l}\text { Adult } \\
\text { Population }\end{array}$ & 7821 & CS & $79.8 \%$ & NA \\
\hline $\begin{array}{l}\text { Chen et } \\
\text { al. [82] }\end{array}$ & 2021 & $\begin{array}{l}\text { Not } \\
\text { explained }\end{array}$ & China & $\begin{array}{l}\text { Adult } \\
\text { Population }\end{array}$ & 3195 & CS & $76.6 \%$ & NA \\
\hline $\begin{array}{l}\text { La Vecchia } \\
\text { et al. [83] }\end{array}$ & 2020 & $\begin{array}{l}\text { September } \\
16 \text { to } 28 \\
2020\end{array}$ & Italy & $\begin{array}{l}15-85 \text { years } \\
\text { Population }\end{array}$ & 1055 & CS & $53.7 \%$ & NA \\
\hline $\begin{array}{l}\text { Largent et } \\
\text { al. [84] }\end{array}$ & 2020 & $\begin{array}{l}\text { September } \\
14 \text { to } 27 \\
2020\end{array}$ & US & $\begin{array}{l}\text { Adult } \\
\text { Population }\end{array}$ & 2730 & CS & $61.4 \%$ & NA \\
\hline $\begin{array}{l}\text { El-Elimat et } \\
\text { al. [85] }\end{array}$ & 2021 & $\begin{array}{l}\text { November } \\
2020\end{array}$ & Jordan & $\begin{array}{l}\text { Adult } \\
\text { Population }\end{array}$ & 3,100 & CS & $66.5 \%$ & NA \\
\hline $\begin{array}{l}\text { Graeber et } \\
\text { al. [86] }\end{array}$ & 2021 & $\begin{array}{l}\text { June and } \\
\text { July } 2020\end{array}$ & Germany & $\begin{array}{l}\text { Adult } \\
\text { Population }\end{array}$ & 851 & CS & $70 \%$ & NA \\
\hline $\begin{array}{l}\text { Al- } \\
\text { Marshoudi } \\
\text { et al. [87] }\end{array}$ & 2021 & $\begin{array}{l}\text { December15 } \\
\text { to } 31,2020\end{array}$ & Oman & $\begin{array}{l}\text { Adult } \\
\text { Population }\end{array}$ & 3000 & CS & $59.3 \%$ & $\begin{array}{l}\text { Gender (male), } \\
\text { history of chronic } \\
\text { disease, } \\
\text { pregnancy, } \\
\text { perceived } \\
\text { vaccine safety, } \\
\text { education levels, } \\
\text { and occupation. }\end{array}$ \\
\hline $\begin{array}{l}\text { Villarreal- } \\
\text { Garza et } \\
\text { al. [88] }\end{array}$ & 2021 & $\begin{array}{l}\text { March } 12 \text { to } \\
26,2021\end{array}$ & Mexico & $\begin{array}{l}\text { Breast Cancer } \\
\text { patients }\end{array}$ & 540 & CS & $66 \%$ & $\begin{array}{l}\text { Age, having a } \\
\text { close } \\
\text { acquaintance } \\
\text { who did not } \\
\text { experience a } \\
\text { vaccine-related } \\
\text { adverse reaction, } \\
\text { having more } \\
\text { information } \\
\text { about vaccine } \\
\text { effectiveness, } \\
\text { mandatory } \\
\text { vaccination, and } \\
\text { being } \\
\text { recommended by } \\
\text { their oncologist } \\
\text { to be vaccinated. }\end{array}$ \\
\hline $\begin{array}{l}\text { Jiang et } \\
\text { al. [89] }\end{array}$ & 2021 & $\begin{array}{l}\text { Mid-March } \\
2021\end{array}$ & China & $\begin{array}{l}\text { nursing } \\
\text { college } \\
\text { students }\end{array}$ & 1,488 & CS & $70.07 \%$ & NA \\
\hline $\begin{array}{l}\text { Omar and } \\
\text { Hani [90] }\end{array}$ & 2021 & $\begin{array}{l}\text { January } 7 \text { to } \\
\text { March 30, } \\
2021\end{array}$ & Egypt & $\begin{array}{l}\text { Adult } \\
\text { population }\end{array}$ & 1011 & CS & $46 \%$ & $\begin{array}{l}\text { Gender (female), } \\
\text { residence } \\
\text { (urban), } \\
\text { educational level } \\
\text { (university/post } \\
\text { graduate), } \\
\text { marital status } \\
\text { (married), having } \\
\text { flu vaccine, and } \\
\text { lack of the }\end{array}$ \\
\hline
\end{tabular}




\begin{tabular}{|c|c|c|c|c|c|c|c|c|}
\hline & & & & & & & & $\begin{array}{l}\text { confidence in the } \\
\text { healthcare } \\
\text { system to control } \\
\text { epidemic. }\end{array}$ \\
\hline $\begin{array}{l}\text { Cai et } \\
\text { al. [91] }\end{array}$ & 2021 & $\begin{array}{l}\text { November } \\
27,2020 \\
\text { and March } \\
12,2021\end{array}$ & China & $\begin{array}{l}\text { Adolescent } \\
\text { population }\end{array}$ & 1,057 & CS & $75.59 \%$ & $\begin{array}{l}\text { Age (younger), } \\
\text { heard about } \\
\text { COVID-19 } \\
\text { vaccines, believe } \\
\text { in COVID-19 } \\
\text { vaccines } \\
\text { protection from } \\
\text { COVID-19 } \\
\text { infection, and } \\
\text { those who } \\
\text { encouraged their } \\
\text { family members } \\
\text { and friends to } \\
\text { get vaccinated, } \\
\text { and believing } \\
\text { that vaccines are } \\
\text { safe. }\end{array}$ \\
\hline $\begin{array}{l}\text { Kuhn et } \\
\text { al. [51] }\end{array}$ & 2021 & $\begin{array}{l}\text { December } \\
2020 \text { to } \\
\text { January } \\
2021\end{array}$ & USA & PEH & 90 & CS & $52 \%$ & NA \\
\hline $\begin{array}{l}\text { Petravić et } \\
\text { al. [92] }\end{array}$ & 2021 & $\begin{array}{l}\text { December } \\
17 \text { to } 27 \\
2020\end{array}$ & Slovenia & $\begin{array}{l}\text { Residents }>15 \\
\text { years }\end{array}$ & 12,042 & CS & $33 \%$ & NA \\
\hline $\begin{array}{l}\text { Kumari et } \\
\text { al. [93] }\end{array}$ & 2021 & $\begin{array}{l}\text { March } 13 \text { to } \\
25,2021\end{array}$ & India & $\begin{array}{l}\geq 18 \text { years } \\
\text { population }\end{array}$ & 1294 & CS & $83.6 \%$ & NA \\
\hline
\end{tabular}

Notice: SP; study period, SS; sample size, SD; study design, CS; cross sectional, HCWs, healthcare workers, NA; not applicable, HICU, household income per consumption unit, $\mathrm{PEH}$; People experiencing homelessness.

\section{Figures}




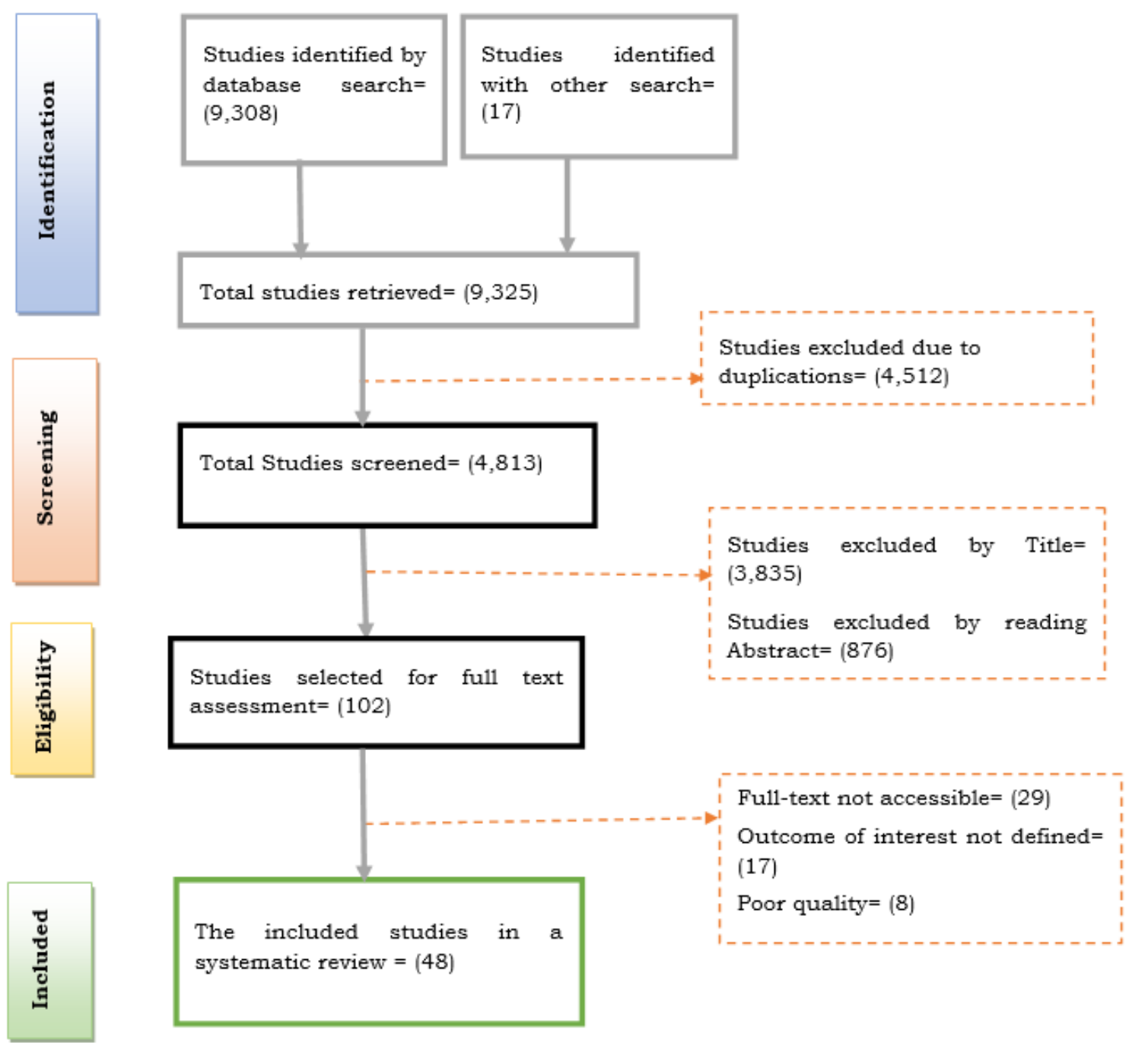

Figure 1

PRISMA Flowchart diagram of the study selection for Systematic Review on Pro-Vaccination Attitude, and Associated Factors Towards COVID-19 Vaccine among HCWs and Non-HCWs globally.

\section{Supplementary Files}

This is a list of supplementary files associated with this preprint. Click to download.

- PRISMA2009ChecklistforProVaccinationAttitudeandAssociatedFactorsTowardsCOVID19Vaccine.doc 